\title{
Effects and interactions of LH and LHRH agonist on testicular morphology and function in hypophysectomized rats
}

\author{
J. B. Kerr* and R. M. Sharpe \\ M.R.C. Reproductive Biology Unit, Centre for Reproductive Biology, 37 Chalmers Street, \\ Edinburgh EH3 9EW, U.K.
}

\begin{abstract}
Summary. The effects of single or combined daily treatment with an LHRH agonist and low or high doses of LH upon the testes of adult hypophysectomized rats were studied for up to 2 weeks in which changes in testicular histology, particularly the interstitial tissue, were examined by morphometry and related to functional assessment of the Leydig cells in vivo and in vitro. Compared to saline-treated controls, LHRH agonist treatment did not alter testis volume or the composition of the seminiferous epithelium or any of the interstitial tissue components although serum testosterone and in-vitro testosterone production by isolated Leydig cells were significantly reduced. With $2 \mu \mathrm{g} \mathrm{LH}$ for treatment, testis volume was increased, spermatogenesis was qualitatively normal, total Leydig cell volume was increased, serum testosterone values were initially elevated but subsequently declined and in-vitro testosterone production was enhanced. Testis volume with $20 \mu \mathrm{g} \mathrm{LH}$ treatment was unchanged compared to saline treatment, the seminiferous epithelium exhibited severe disruption but total Leydig cell volume was greatly increased due to interstitial cell hyperplasia. This group showed elevated serum testosterone concentrations and major increases in testosterone production in vitro. Treatment with LHRH agonist with either dose of LH resulted in reduced testis volume, moderate to very severe focal spermatogenic disruption and increased total Leydig cell volume although serum testosterone values and in-vitro testosterone production were markedly reduced compared to control rats. It is concluded that, in the absence of the pituitary, LHRH agonist fails to disrupt spermatogenesis and the previously described antitesticular action of LHRH agonists in intact rats is therefore dependent upon the presence of $\mathrm{LH}$, which alone or in combination with LHRH agonist, may focally disrupt spermatogenesis in hypophysectomized rats whereas the Leydig cells undergo hyperplasia. The findings show that impairment of spermatogenesis is accompanied by alterations of the interstitial tissue and suggest that communication between these two compartments is involved in the regulation of testicular function.
\end{abstract}

\section{Introduction}

Although it is now well established that treatment with LHRH agonists can result in major inhibition of testicular function in a number of species, including man (see reviews by Hsueh \& Jones, 1981; Sandow, 1982; Jones \& Hsueh, 1984), at least two important aspects of this inhibition remain unclear and controversial. The first of these centres on the mechanism of action of the LHRH agonists in bringing about impaired spermatogenesis and infertility. Do their inhibitory effects result from modulation of pituitary gonadotrophin release or do they arise, wholly or in part, from

\footnotetext{
* Present address: Department of Anatomy, Monash University, Clayton, Victoria 3168, Australia.
} 
direct effects on the testis? There is evidence to support the latter possibility since in the rat at least, LHRH agonists may exert both stimulatory and inhibitory effects directly on the Leydig cells (Sharpe, Doogan \& Cooper, 1983a; Sharpe, 1984), the nature of the effect depending on the duration of exposure to the LHRH agonist and the degree of concomitant stimulation with LH (Sharpe, Doogan \& Cooper, 1983b).

The second unresolved question is what effect do LHRH agonists have upon spermatogenesis and testicular morphology in general, as reports in the literature are somewhat equivocal? Thus, in certain species, notably man (Linde et al., 1981; Rabin, Linde, Doelle \& Alexander, 1981), monkeys (Akhtar, Marshall, Wickings \& Nieschlag, 1983; Akhtar, Wickings \& Nieschlag, 1984) and the dog (Tremblay \& Belanger, 1984; Vickery et al., 1984), suppression of sperm output can be achieved by peripheral administration of LHRH agonists, whilst in the rat only a partial reduction in sperm output occurs (Heber \& Swerdloff, 1981) and fertility is often maintained (Vickery et al., 1983). Suppression of spermatogenesis by LHRH agonists is commonly considered to be secondary to impairment of Leydig cell steroidogenesis and testosterone secretion which occurs both in intact (Rivier, Rivier \& Vale, 1979; Labrie et al., 1980a, b; Wang et al., 1983) and in hypophysectomized rats (Hsueh \& Erickson, 1979; Bambino, Schreiber \& Hsueh, 1980; Wang et al., 1983). Despite impairment of steroidogenesis, the morphology of the Leydig cells has been reported to be either unchanged from normal (Labrie et al., 1978, 1980b; Pelletier et al., 1978, 1980; Lefebvre, Belanger, Pelletier \& Labrie, 1984), atrophic (Rivier et al., 1979; Rajfer, Swerdloff \& Heber, 1984) or hyperplastic (Vickery et al., 1983). However, the degree of histological preservation of the testes in these studies was not of sufficient quality to evaluate these conclusions. Little information is available on the changes in testicular morphology which precede the reduction in sperm output and, as yet, no study has provided a clear indication of the morphological consequences of the direct actions of LHRH agonists on the testis. The aim of the present study was therefore to clarify some of the above points by examining changes in testicular structure, with particular attention to the Leydig cells, in hypophysectomized adult rats treated for 12-14 days with a low or high dose of $\mathrm{LH}$, an LHRH agonist or the two hormones in combination. The morphological and morphometric data obtained were related to functional assessment of the Leydig cells in vitro and in vivo.

\section{Materials and Methods}

Animals and treatments. Sprague-Dawley rats hypophysectomized at 52 days of age were obtained from Charles River (U.K.) Ltd, Margate, Kent, U.K. and treatment begun 5-6 days postoperatively. Rats were maintained under standard conditions except that glucose $(2.5 \mathrm{mg} / \mathrm{ml})$ was added to the drinking water. Groups of 8 rats were then treated once daily at 09:00-10:00 $\mathrm{h}$ (subcutaneous injection) for 12 or 14 days with one of the following:

(1) $0.5 \mathrm{ml}$ vehicle, consisting of $0.9 \%(\mathrm{w} / \mathrm{v}) \mathrm{NaCl}, 2.5 \mathrm{mg}$ gelatin $/ \mathrm{ml}$ (Sigma, Poole, U.K.) and $2.5 \mathrm{mg}$ bovine serum albumin $/ \mathrm{ml}$ (BSA, fraction V; Sigma);

(2) $100 \mathrm{ng}$ LHRH agonist [(D-Ser- $t$-bu ${ }^{6}$,des-Gly- $\mathrm{NH}_{2}{ }^{10}$ ) LHRH ethylamide; Hoechst, A.G., F.R.G.] in $0.5 \mathrm{ml}$ vehicle;

(3) $2 \mu$ g NIAMDD ovine $\mathrm{LH}-\mathrm{S} 24$ in $0.5 \mathrm{ml}$ vehicle;

(4) $20 \mu \mathrm{g}$ ovine LH-S24 in $0.5 \mathrm{ml}$ vehicle;

(5) $2 \mu \mathrm{g}$ ovine $\mathrm{LH}-\mathrm{S} 24+100 \mathrm{ng}$ LHRH agonist in $0.5 \mathrm{ml}$ vehicle;

(6) $20 \mu \mathrm{g}$ ovine LH-S24 $+100 \mathrm{ng}$ LHRH agonist in $0.5 \mathrm{ml}$ vehicle.

Hormone solutions were made up fresh every $48 \mathrm{~h}$ and kept at $4^{\circ} \mathrm{C}$. All animals selected for treatment had body weights within the range $168-197 \mathrm{~g}$ at the start of the experiment and the change in bodyweight was monitored throughout the treatment period. Animals showing a bodyweight increment in excess of $10 \mathrm{~g}$ from Days 1 to 8 (5 rats) were discarded from the experiment and all 
of these were subsequently confirmed to have remnants of pituitary tissue present upon visual inspection of the pituitary fossa. A further rat was discarded on the latter basis at Day 14.

Tissue fixation. The testes of 3 animals from each treatment group together with 3 age-matched intact animals were fixed by perfusion on Day 12 . Under deep ether anaesthesia the thoracic aorta was cannulated, the right atrium severed and testes were perfused for $30 \mathrm{sec}$ with $0.9 \%(\mathrm{w} / \mathrm{v}) \mathrm{NaCl}$. A mixture of $3 \%$ glutaraldehyde, $2 \%$ formaldehyde and $0.01 \%$ trinitrophenol buffered with $0 \cdot 2 \mathrm{M}$-cacodylate, $\mathrm{pH} 7 \cdot 2$, was perfused for $10 \mathrm{~min}$ and then $5 \%$ glutaraldehyde, $3 \%$ formaldehyde and $0.01 \%$ trinitrophenol in the same buffer was perfused for $30 \mathrm{~min}$. Testes were removed, trimmed of fat and connective tissue and the volume of each pair of decapsulated testes was measured by water displacement (Elias \& Hyde, 1980). Slices of testes from apical, equatorial and caudal regions were cut with razor blades into blocks $1-2 \mathrm{~mm}$ on edge and fixed for $2 \mathrm{~h}$ in the latter fixative. Blocks were post-fixed in osmium tetroxide, stained en bloc with uranyl acetate, dehydrated in graded ethanols, cleared in propylene oxide and embedded in Epon-araldite. All specimens were processed identically and on the same day. Sections were cut at $1 \mu \mathrm{m}$ with glass knives on a Reichert OmU3 ultratome, were stained with toluidine blue and examined and photographed with a Zeiss photomicroscope.

Morphometric analysis. Blocks from all testes were examined by light microscopy to exclude from study any tissue which showed evidence of fixation or preparation artefacts. Any blocks exhibiting artefactual spaces between the tunica propria of the seminiferous tubules and the interstitial tissue, shrinkage artefacts within the interstitial spaces or unsatisfactory preservation of the interstitial cells were not assigned for quantitative analysis. Of the blocks exhibiting superior morphological preservation, 10 were selected from each testis in which seminiferous tubules were predominantly cut in transverse section. Stained sections were examined by light microscopy using $\times 10$ eyepieces and a $\times 25$ objective lens. The volumetric densities of Leydig cells, interstitial spaces (lymphatic sinusoids), blood vessel lumina (arteries, veins, capillaries) and remaining interstitial cells (endothelium, blood vessel pericytes, macrophages, leucocytes and connective tissue cells) were measured by a point-counting method (Weibel, 1979) using an eyepiece graticule of 121 points $(11 \times 11$ squares $)$ inserted into one eyepiece. The volumetric density of each component was determined on 6 different areas of each section and expressed as a percentage of the total number of points superimposed upon the tissue section. For each animal 14520 points were counted (121 points $\times 6$ areas $\times 10$ blocks $\times 2$ testes). Average volumetric densities for the measured components were calculated for each testis and for each animal. The volume of the testis occupied by each component was obtained by multiplying the volumetric density by the previously measured volume of the same perfusion-fixed testis. Changes in the volume of testes which may occur during post-fixation and processing of tissue blocks were not measured since the principal interest of the morphometric study was to compare the morphology of the testis from saline-treated rats with testes from hormone-treated rats. Conversion of the quantitative data from fixed tissues to values relating to the fresh testis was therefore unnecessary. Average volumetric densities and absolute volumes of the components within a group were determined by calculation of the mean \pm standard deviation for that group.

Collection of blood samples. Blood samples $(1-1.5 \mathrm{ml})$ were obtained at $2 \mathrm{~h}$ after the daily injection on Days 1, 3, 7 and 13 of the experiment by incision of the tail vein under light ether anaesthesia, and the serum was stored at $-20^{\circ} \mathrm{C}$. Animals (3/group) in which the testes were fixed by perfusion fixation (Day 12) had blood samples collected only on Days 1, 3 and 7.

Collection of seminal vesicles, testes and preparation of isolated Leydig cells. Other than animals used for perfusion fixation, the remainder were killed using solid $\mathrm{CO}_{2}$-generated $\mathrm{CO}_{2}$ on Day 14 of the experiment, i.e. $24 \mathrm{~h}$ after the last injection. After inspection of the pituitary fossa for remnants of tissue, the seminal vesicles were dissected and weighed and the paired testes were removed, weighed and decapsulated. Using 8 testes/treatment group, a suspension of isolated testicular cells 
was then prepared using collagenase as described elsewhere (Sharpe \& Fraser, 1983). The isolated cells were suspended in Medium 199, to which was added Earle's salts, $\mathrm{NaHCO}_{3}(0 \cdot 22 \%)$, Lglutamine (2 mM; Flow Labs, Irvine, U.K.), transferrin ( $5 \mu \mathrm{g} / \mathrm{ml}$; Sigma), insulin (10 $\mathrm{gg} / \mathrm{ml}$; Sigma), ceruloplasmin (1 U/ml; Sigma), penicillin (100 i.u./ml; Flow Labs), streptomycin (100 $\mu \mathrm{g} / \mathrm{ml}$; Flow Labs), fungizone ( $2.5 \mu \mathrm{g} / \mathrm{ml}$; Flow Labs) and BSA $(0.5 \mathrm{mg} / \mathrm{ml}$; Sigma). For each treatment group, samples of $0.275 \times 10^{6}$ nucleated cells were dispensed into plastic multiwell dishes (Nunc; Kamstrup, Denmark) and incubated in a final volume of $0.65 \mathrm{ml}$ in the absence or presence of a supra-maximally stimulating concentration of $\mathrm{hCG}\left(10^{-7} \mathrm{M}\right.$; Chorulon, Intervet, Cambridge, U.K.) or an LHRH agonist $\left(10^{-7} \mathrm{M}\right.$; details given above). Incubation was for $4 \mathrm{~h}$ at $32^{\circ} \mathrm{C}$ under a humidified atmosphere of $95 \%$ air; $5 \% \mathrm{CO}_{2}$, after which the medium was aspirated, centrifuged for $5 \mathrm{~min}$ at $1000 \mathrm{~g}$ and then stored at $-20^{\circ} \mathrm{C}$ for testosterone measurement. Air-dried smears of cells from each of the treatment groups were also prepared, fixed in acetone and stained for $3 \beta$-hydroxysteroid dehydrogenase (3ß-HSD; EC 1.1.1.145) in the presence of sodium cyanide (to suppress the diaphorase enzyme), to identify the proportion of Leydig (3$\beta$-HSD-positive) cells; full details of this procedure have been given elsewhere (Sharpe \& Fraser, 1983). Testosterone production by the isolated cells has been expressed in $\mathrm{ng} / 10^{6} 3 \beta$-HSD-positive cells.

Measurement of testosterone. Testosterone concentrations in serum were measured by radioimmunoassay after extraction with 10 volumes of hexane:diethyl ether $(4: 1, \mathrm{v} / \mathrm{v})$ as described and validated by Corker \& Davidson (1978). Assay of Leydig cell incubation media before and after extraction, as described above, gave comparable testosterone values $(P>0.2$ by Student's $t$ test; $n=48$ ), and unextracted diluted incubation media gave displacement curves parallel to the testosterone standard $(P>0.2$ in a test of non-parallelism using 2-factor analysis of variance with replication). Incubation media were therefore assayed directly after appropriate dilution (between $1 / 20$ and $1 / 500$ ), and the limit of detection of the assay was $5 \mathrm{pg}$ testosterone/sample. All samples of incubation medium or serum were assayed together in a single assay and the intra-assay coefficient of variation was $<5 \%$.

Statistical analysis. For the functional studies, results were analysed using 2-factor analysis of variance (with replication) and Student's $t$ test. For morphometric studies, the effects of hormone treatment compared to saline treatment of hypophysectomized rats were analysed using Duncan's new multiple range test. Comparison between values for the normal testis and saline-treated hypophysectomized rats was made using two-tailed Student's $t$ tests.

\section{Results}

\section{Gross morphology}

After perfusion fixation the mean \pm s.d. volume of testes from saline-treated hypophysectomized rats $\left(0.442 \pm 0.027 \mathrm{~cm}^{3}\right)$ was significantly smaller $(P<0.05)$ than that of testes from normal intact rats $\left(1.248 \pm 0.05 \mathrm{~cm}^{3}\right)$. Amongst the groups of hormone-treated hypophysectomized rats, testes from rats treated with $2 \mu \mathrm{g} \mathrm{LH}\left(0.741 \pm 0.081 \mathrm{~cm}^{3}\right)$ were significantly $(P<0.01)$ larger than those of saline-treated rats, whilst testes from rats treated with $20 \mu \mathrm{g} \mathrm{LH}+\mathrm{LHRH}$ agonist $\left(0.281 \pm 0.28 \mathrm{~cm}^{3}\right)$ were significantly $(P<0.05)$ smaller than those from saline-treated rats. No significant differences were noted for other hormone treatments (see Fig. 11). Comparable differences as above were obtained for the weights of fresh testes allocated for functional studies. Visual examination of fixed testes from rats treated with $20 \mu \mathrm{g} \mathrm{LH}, 2 \mu \mathrm{g} \mathrm{LH}+\mathrm{LHRH}$ agonist or $20 \mu \mathrm{g}$ LH + LHRH agonist revealed the presence of opaque intratesticular densities beneath the tunica albuginea, particularly in the caudal pole of the testes. Although the weight of seminal vesicles from rats treated with $20 \mu \mathrm{g} \mathrm{LH}$ alone was larger $(69 \pm 34 \mathrm{mg}$, mean \pm s.d.) compared to salinetreated control rats $(33 \pm 14 \mathrm{mg})$, this difference and other comparisons did not reach statistical significance. 


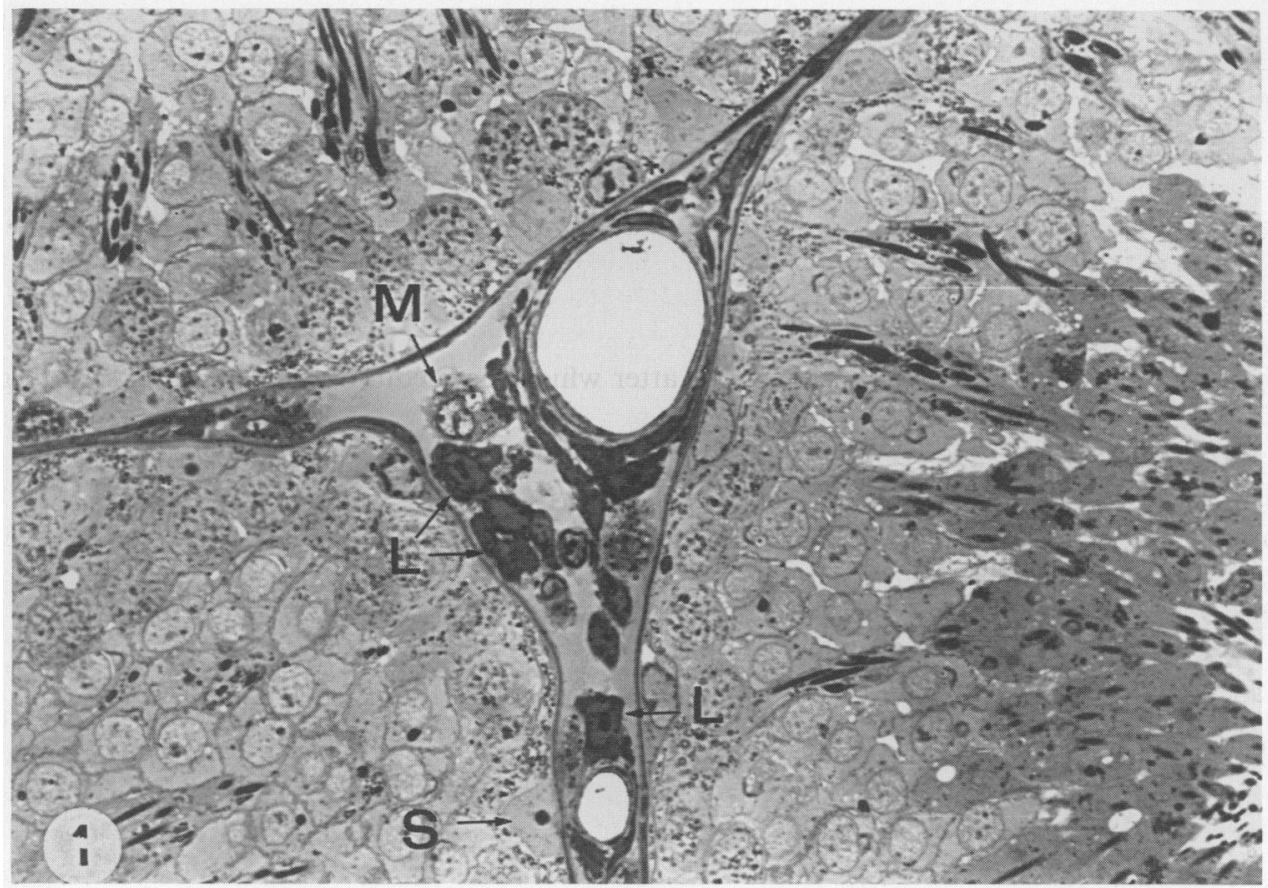

Fig. 1. Normal adult rat testis illustrating full spermatogenesis and interstitial tissue of normal morphology. Leydig cells (L), macrophages $(\mathrm{M})$ and Sertoli cell nuclei $(\mathrm{S})$ are shown. $\times 400$.

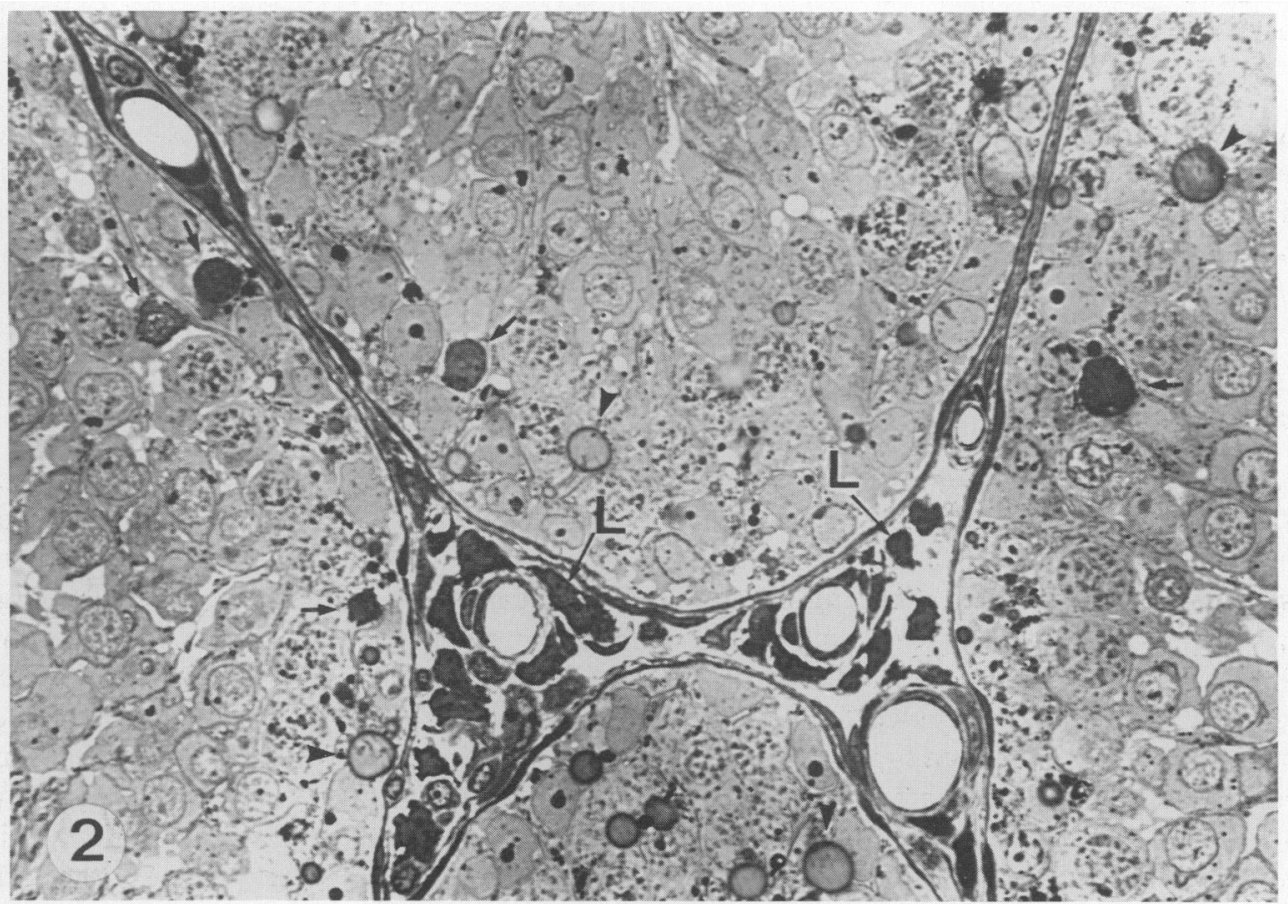

Fig. 2. Vehicle treatment of hypophysectomized rats, illustrating degenerating germ cells (arrows), lipid inclusions (arrowheads) and atrophic Leydig cells (L) in the interstitial tissue. $\times 400$. 


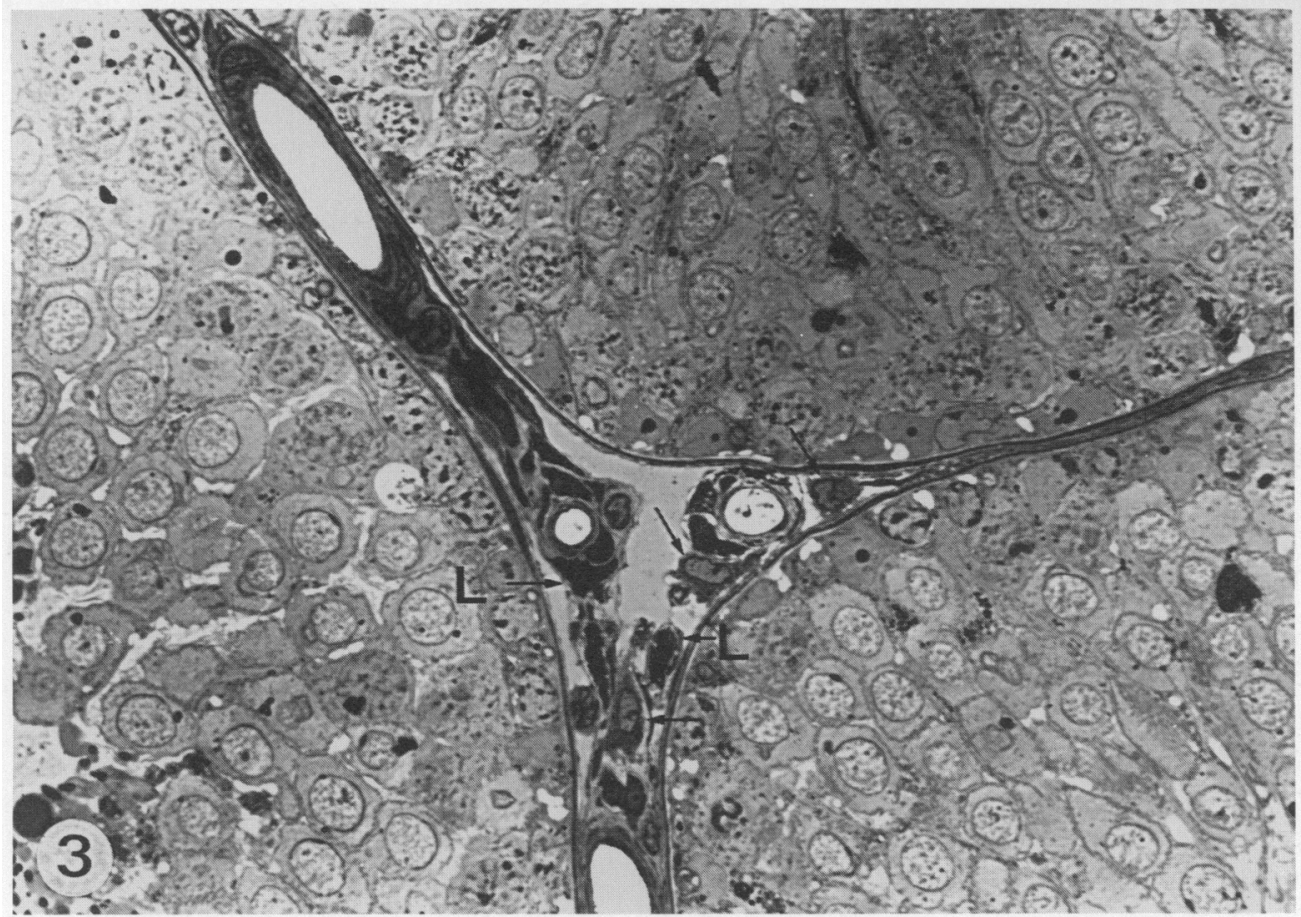

Fig. 3. Treatment of hypophysectomized rats with LHRH agonist. Seminiferous epithelium at stage II (upper) and stage VI (right) lack their usual numbers of elongated spermatids. Macrophages shown by arrows. Leydig cells (L) similar in size to vehicle-treated rats. $\times 400$.

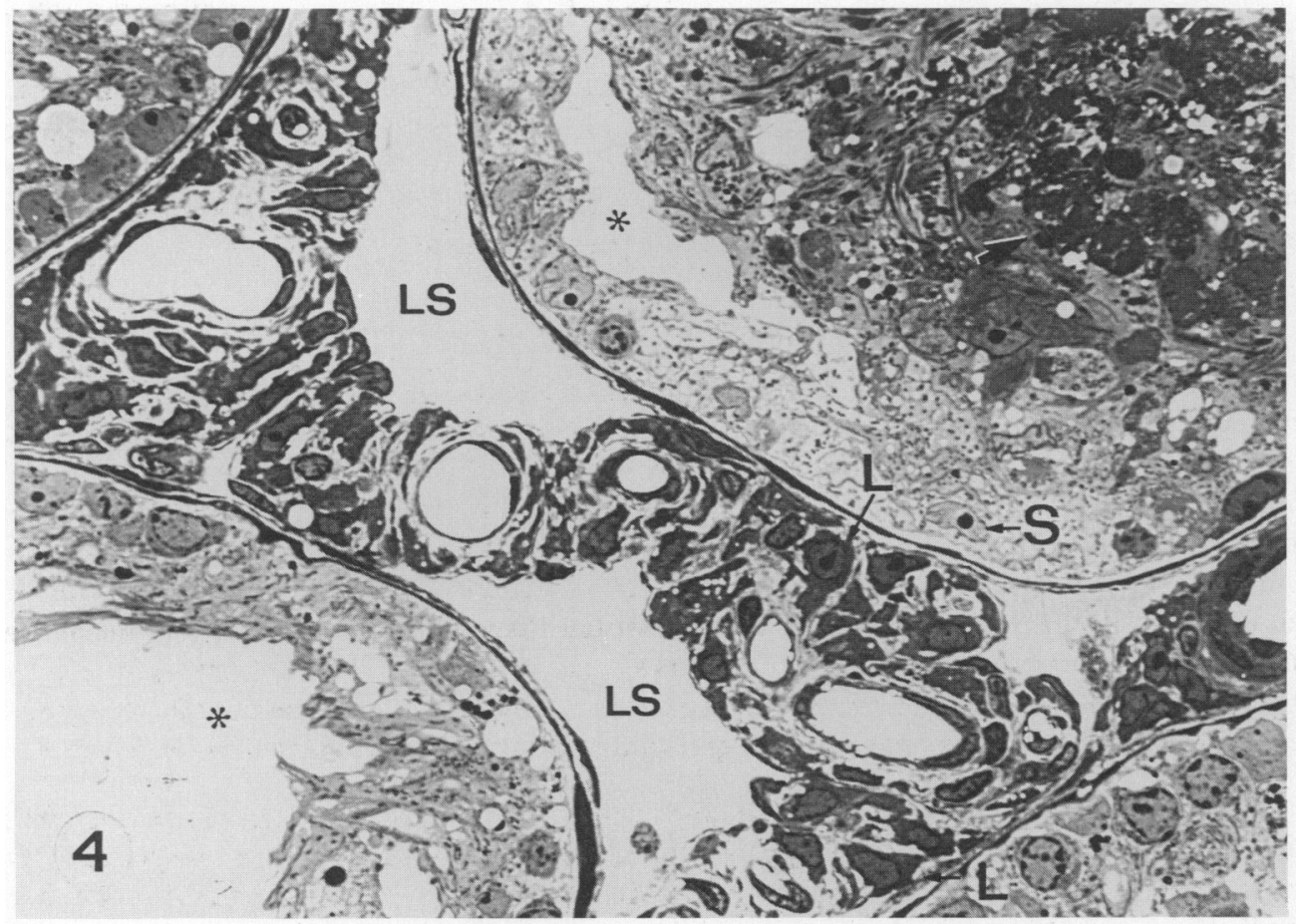

Fig. 4. Treatment of hypophysectomized rats with $20 \mu \mathrm{g} \mathrm{LH}$, illustrating degeneration of seminiferous epithelium and expansion of the interstitial tissue. Sertoli cell nuclei (S) dense intratubular debris (arrow) and spaces (asterisks) are shown. There are abundant Leydig cells (L) and large lymphatic spaces (LS). $\times 400$. 


\section{Histology}

Normal rats. All stages of the spermatogenic cycle were observed in each testis and none of the seminiferous tubules showed evidence of degenerative changes or morphological alterations (Fig. 1). Sertoli cell nuclei were readily visible lying adjacent to the basement membrane of the seminiferous tubules. The interstitial tissue appeared normal, containing clusters of Leydig cells identified by their oval or irregular shape. Leydig cell nuclei exhibited a prominent nucleolus while the cytoplasm was basophilic and contained dense granules representing mitochondria. Macrophages were fewer in number than Leydig cells and were characterized by a pale-staining nucleus and cytoplasm containing numerous vacuoles and inclusion bodies. Thin elongated endothelial cells formed the walls of the interstitial lymphatic sinusoids which appeared as uniformly stained pale spaces partly or at times completely surrounding the interstitial cells, a feature characteristic of the morphology of the interstitial space when optimally fixed by perfusion.

Saline-treated hypophysectomized rats. The seminiferous tubules showed patchy disruption of spermatogenesis with some tubules exhibiting more extensive degeneration of the seminiferous epithelium than others (Fig. 2). All seminiferous tubules contained abnormal accumulations of spherical lipid inclusions. Many tubules lacked one or more generations of germ cells, the elongating and fully developed spermatids being moderately to severely reduced in numbers. Numerous degenerating and pycnotic germ cells were observed, together with vacuoles present within the basal or adluminal regions of the seminiferous epithelium. In the interstitial tissue the principal changes compared to the normal testis were an apparent reduction in the cross-sectional area of the Leydig cells and narrowing of the interstitial lymphatic spaces. Macrophages and other interstitial cells were also present.

LHRH-agonist treatment. The seminiferous tubules showed variable spermatogenic activity with some exhibiting a morphologically normal seminiferous epithelium while the majority showed degenerating and pycnotic germ cells and at times loss of the mature generation of elongated spermatids (Fig. 3). The morphology of the remaining germ cells and the Sertoli cells were, at the light microscope level, indistinguishable from that of the normal testis. However, the interstitial tissue contained Leydig cells with a smaller cross-sectional area than those of the normal testis. Other features of the interstitial tissue did not appear significantly altered when compared to interstitial tissue of saline-treated rats.

Treatment with $2 \mu \mathrm{g} \mathrm{LH}$. Seminiferous tubules were smaller in cross-sectional area compared to the normal testis but larger than those seen in saline-treated rats. Spermatogenesis was qualitatively normal except for the final phase of spermiogenesis when abnormal retention of elongated spermatids was noted together with bizarre profiles of residual bodies at the luminal aspect of the seminiferous tubules. All other germ cells appeared normal in morphology. Most tubules contained increased numbers of lipid inclusions and degenerating germ cells were commonly observed. Plentiful numbers of fully developed spermatids seen at stages VII and VIII in the normal testis were not often observed in this treatment group. The interstitial tissue appeared qualitatively unchanged compared to the normal testis except that the Leydig cells often contained cytoplasmic lipid inclusions, a feature not seen in normal Leydig cells. Macrophages, other interstitial cells and the interstitial space were always observed and appeared unchanged compared to the normal testis.

Treatment with $20 \mu \mathrm{g} \mathrm{LH}$. The cross-sectional area of all seminiferous tubules was markedly reduced compared to the treatment groups described above and different degrees of spermatogenic disruption had occurred ranging from severe to very severe damage to the seminiferous epithelium (Fig. 4). In severely damaged tubules, the seminiferous epithelium consisted of reduced numbers of germ cells with round spermatids being the most mature type present. These tubules also contained variable quantities of lipid inclusions and/or many spherical or irregularly-shaped vacuoles. The most severely disrupted tubules contained relatively few germ cells or at times the complete absence 


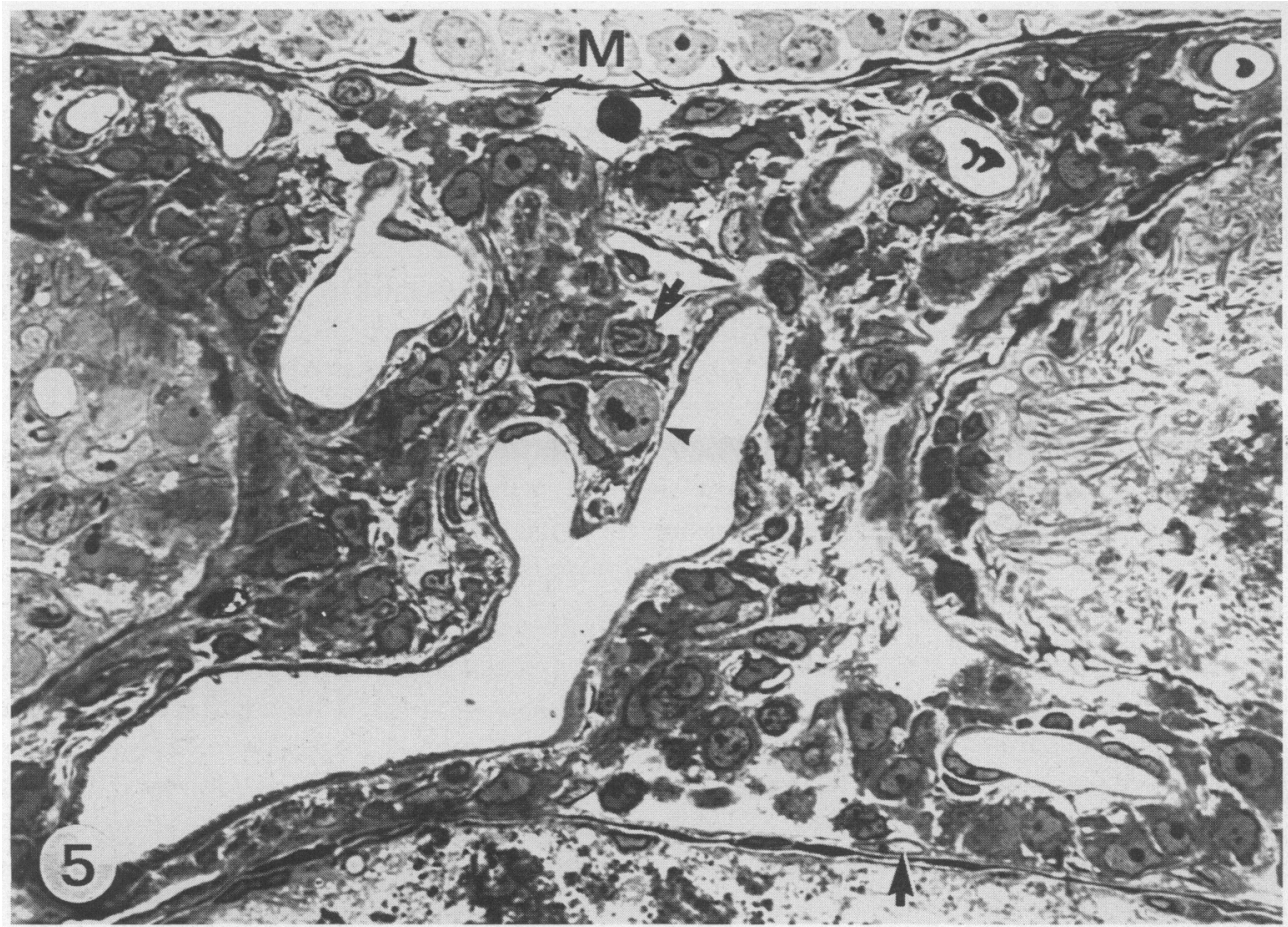

Fig. 5. Treatment of hypophysectomized rats with $20 \mu \mathrm{g} \mathrm{LH}$, showing Leydig cell hyperplasia within a very large interstitial area. Note Leydig cell mitotic figure (arrowhead). Macrophages (M) together with other interstitial cells (arrows) are illustrated. $\times 400$.

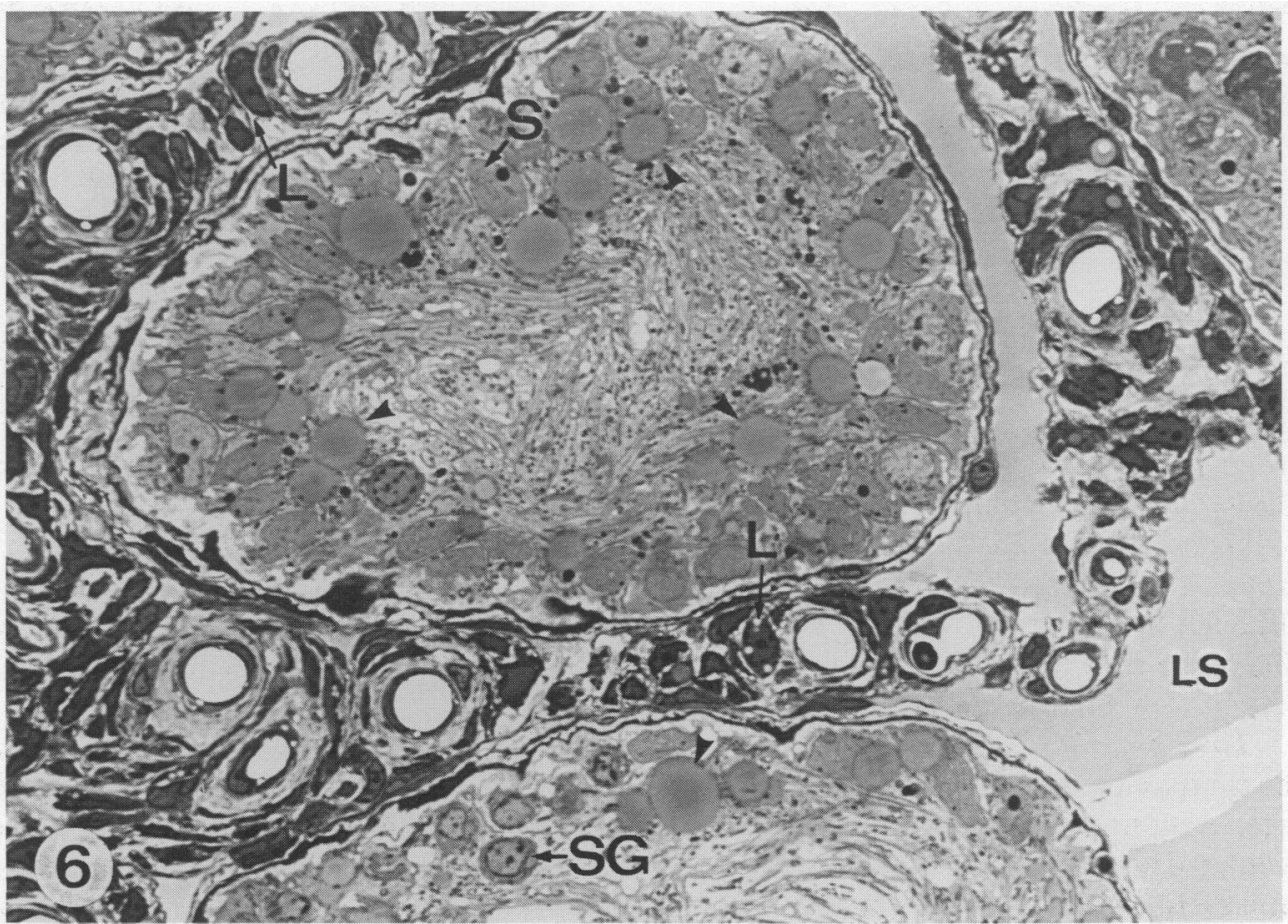

Fig. 6. Treatment of hypophysectomized rats with $20 \mu \mathrm{g}$ LH + LHRH agonist, illustrating collapse of the seminiferous tubules which contain Sertoli cells (S), spermatogonia (SG) and numerous lipid inclusions (arrowheads). Note interstitial cell hyperplasia consisting of Leydig cells $(\mathrm{L})$ and other interstitial cells. Lymphatic spaces (LS) are prominent. $\times 400$. 

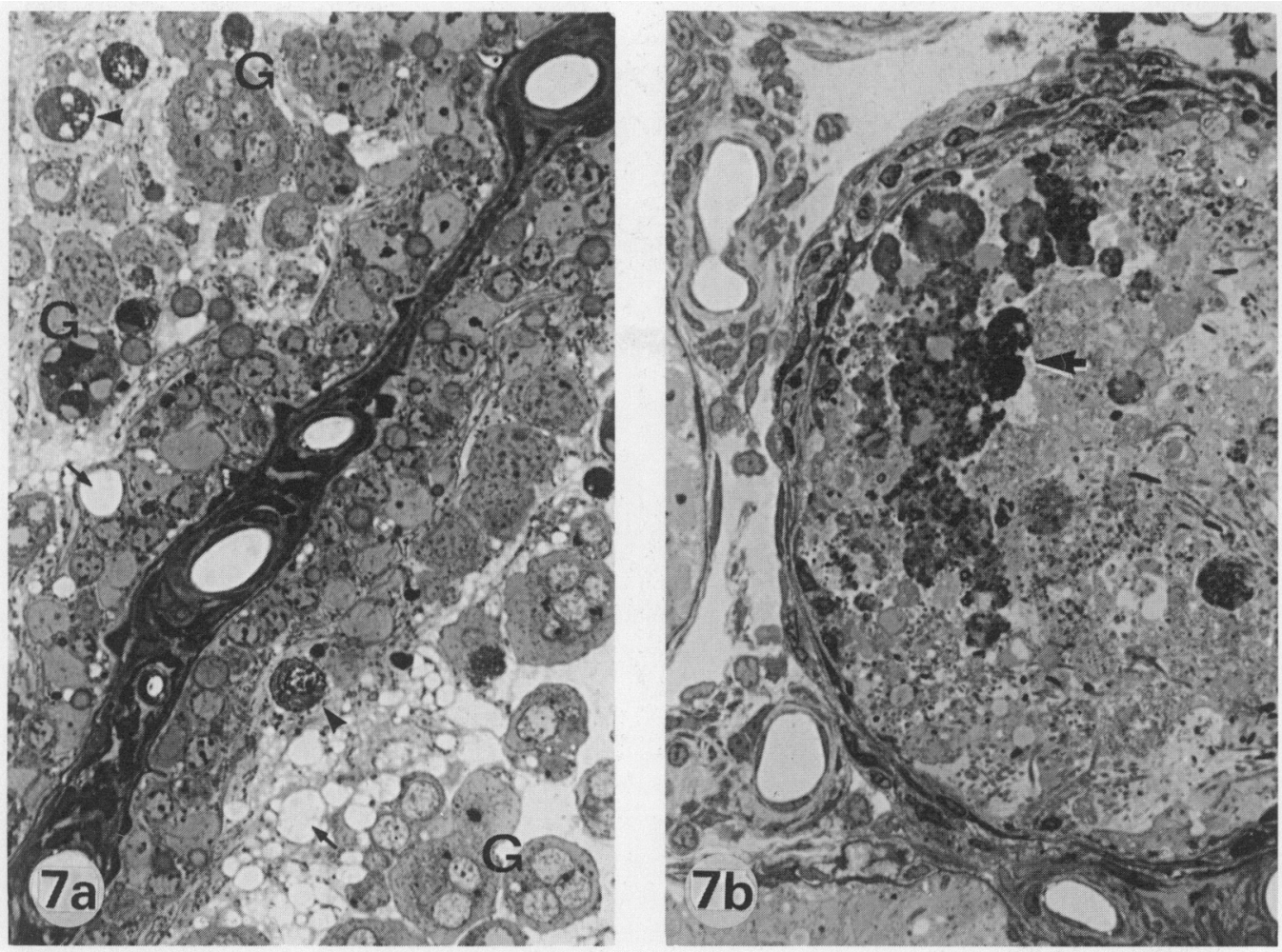

Fig. 7. Treatment of hypophysectomized rats with $2 \mu \mathrm{g}$ LH + LHRH agonist, showing (a) disrupted seminiferous epithelia containing multinucleated germ cells $(G)$, degenerating germ cells (arrowheads) extracellular spaces, vacuoles and vesicles (arrows), and (b) extreme degeneration of the seminiferous epithelium, now filled with a variety of dense tissue debris (arrow). Nuclei of Sertoli cells and germ cells are absent. $\times 300$.

of germ cells. Large extracellular spaces and vacuoles were frequently noted, together with a variable content of lipid inclusions. Sertoli cell nuclei present within such tubules were reduced in numbers and they exhibited pleomorphic morphologies not seen in the above-mentioned treatment groups. Frequently the lumina of the collapsed seminiferous tubules became obliterated, being filled with dense accumulations of cellular debris and in such tubules, germ cells and Sertoli cells could not be identified. Interstitial tissue was markedly expanded compared to the above treatment groups and exhibited interstitial cell hyperplasia (Fig. 5). Leydig cells were especially abundant although they appeared smaller and far more irregular in shape compared to the normal testis. Macrophages and other interstitial cells were commonly observed and many capillaries were present within the interstitial tissue.

Treatment with 2 or $20 \mu \mathrm{g} L H+L H R H$-agonist. These two groups are described together since the morphological response of the testis was similar. The seminiferous tubules were reduced in cross-sectional area due to collapse of the seminiferous epithelium which exhibited a variety of cellular damage ranging from moderate loss of germ cells to elimination of all cells from the seminiferous tubules (Figs $6,7 \mathrm{a} \& \mathrm{~b}$, and $8 \mathrm{a} \& \mathrm{~b}$ ). In those tubules containing germ cells the most advanced cell type seen was the round spermatid although occasionally small numbers of elongating spermatids were present. Seminiferous epithelia of this type contained increased numbers of lipid inclusions and many vacuoles and large empty extracellular spaces. Sertoli cells exhibited 

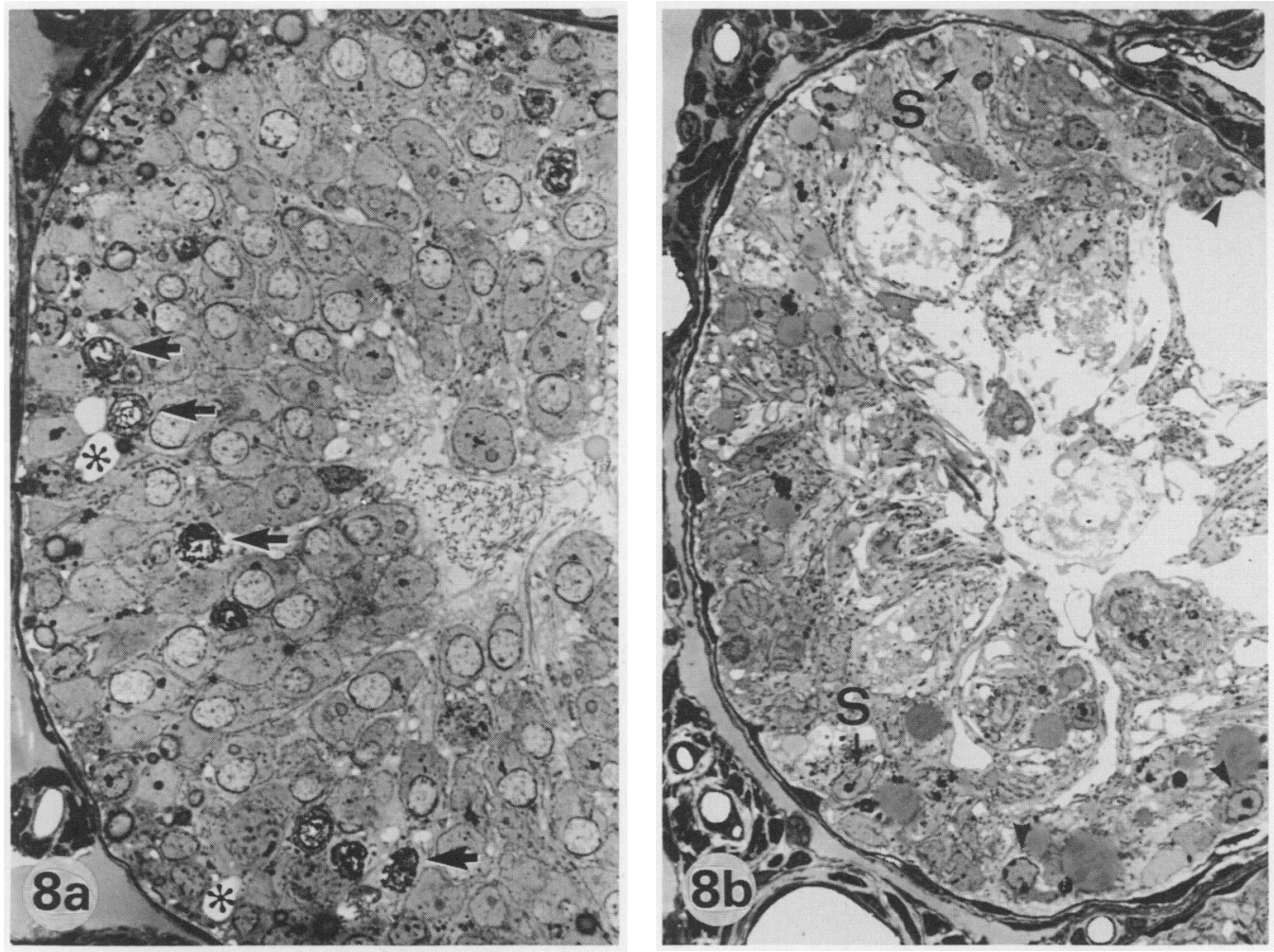

Fig. 8. Treatment of hypophysectomized rats with $20 \mu \mathrm{g} \mathrm{LH}+\mathrm{LHRH}$ agonist showing (a) degenerating germ cells (arrows) and extracellular vacuoles (asterisks), and (b) marked reduction in germ cells and interdigitated processes of Sertoli cell cytoplasm. Nuclei of Sertoli cells (s) and spermatogonia (arrowheads) $\times 300$.

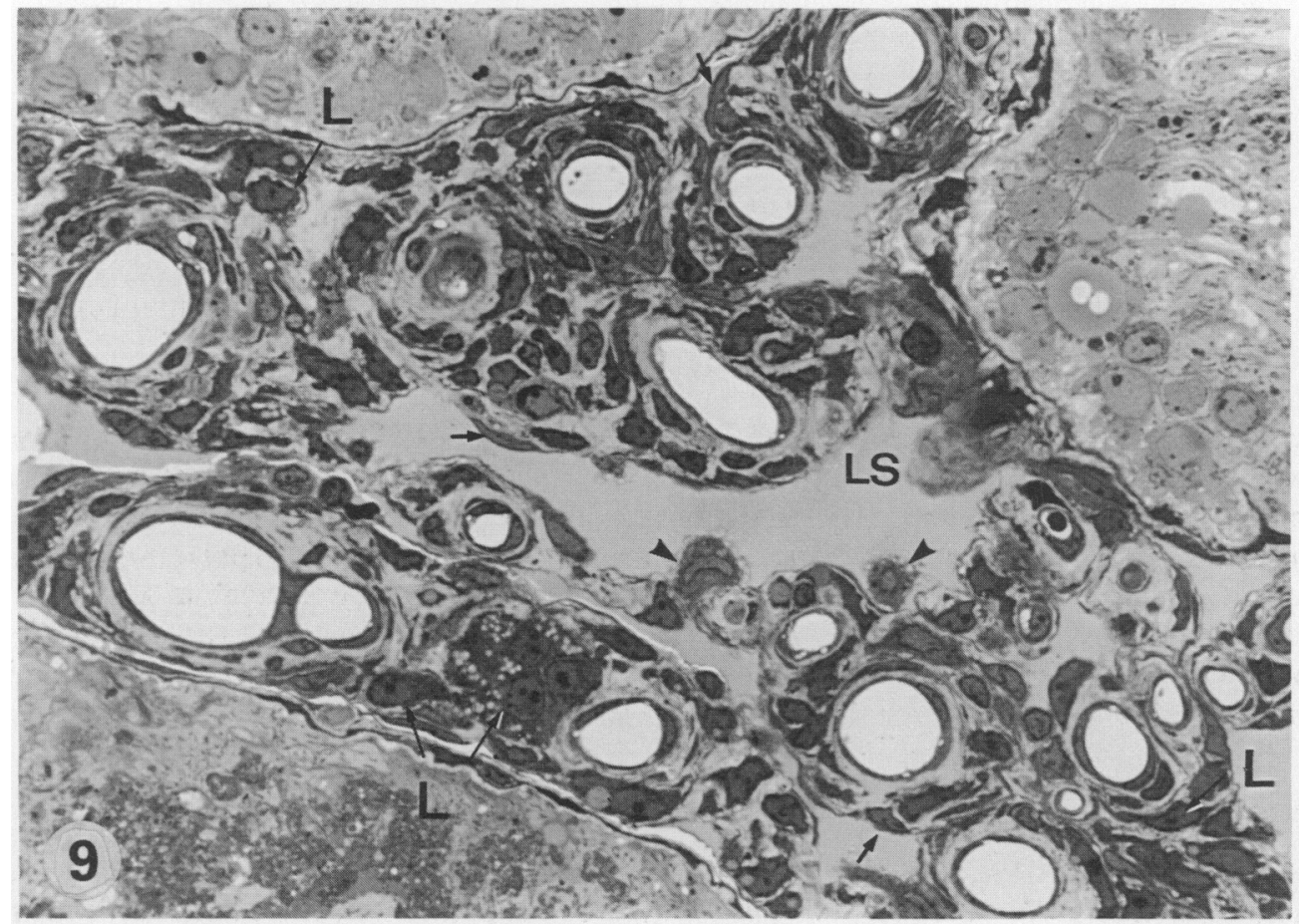

Fig. 9. Treatment of hypophysectomized rats with $20 \mu \mathrm{g} \mathrm{LH}+\mathrm{LHRH}$ agonist showing interstitial cell hyperplasia. Leydig cells (L), macrophages (arrowheads) and other interstitial cells (arrows) are indicated. Note abundant empty capillaries, and lymphatic spaces (LS). $\times 400$. 


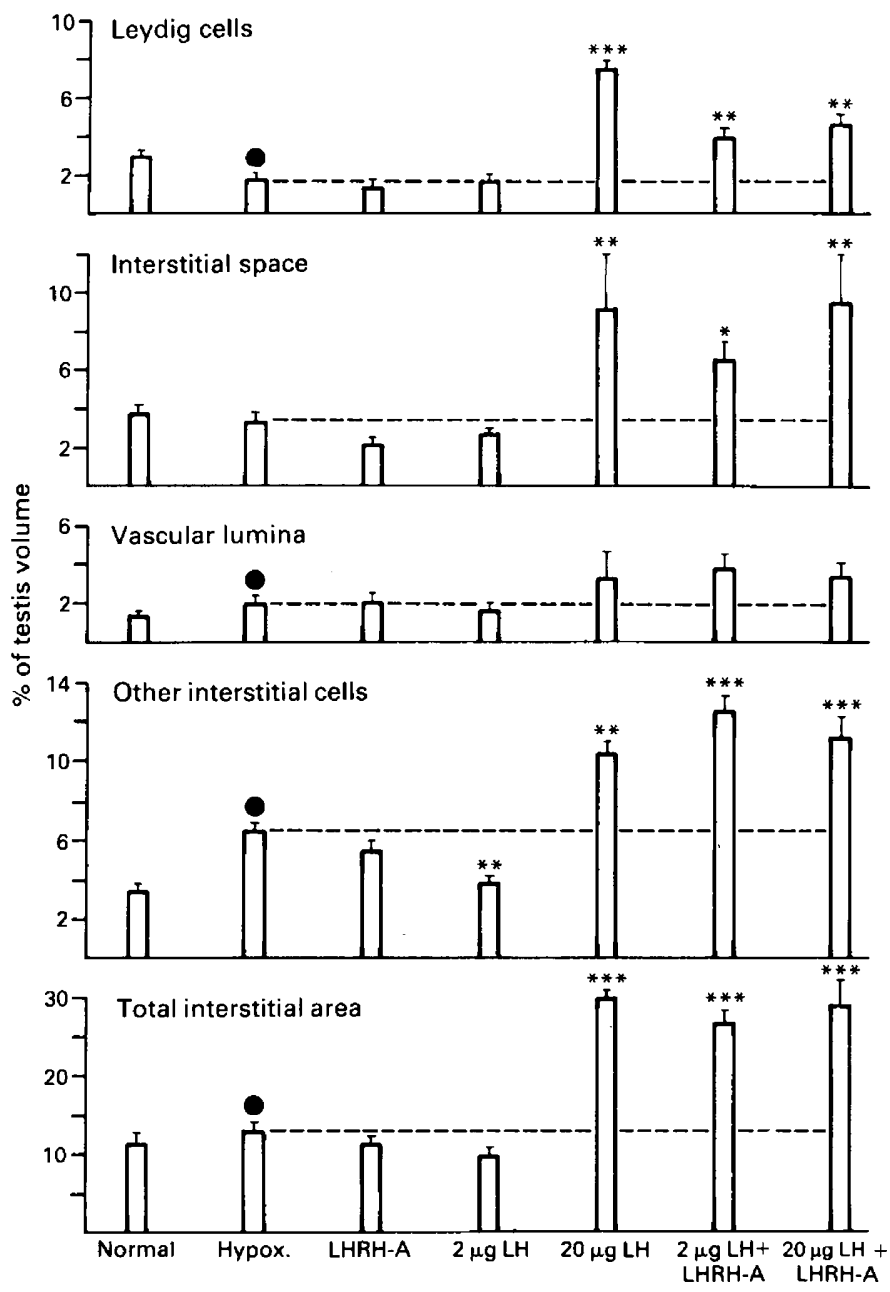

Fig. 10. Volumetric densities of the interstitial compartment and its components in the testis of the normal intact adult rat and in the testis of saline- or hormone-treated adult hypophysectomized rats. Values expressed as means \pm s.d., $n=3$ in each group. $O, P<0.05$ compared with value for normal testis; ${ }^{*} P<0.05,{ }^{* *} P<0.01,{ }^{* * *} P<0.001$ compared with value for saline-treated hypophysectomized rats.

nuclei of irregular shapes, often displaced towards the lumen of the tubules and their cytoplasm formed branching networks. In the most severely damaged tubules, germ cells were markedly depleted or absent, the lumen was either filled with interdigitating processes of Sertoli cell cytoplasm or contained remarkable accumulations of dense basophilic material suggestive of undigested cellular debris. Sertoli cells and germ cells were often not present within such tubules. The morphology of the interstitial tissue was similar to that observed in the $20 \mu \mathrm{g} \mathrm{LH}$ treatment group, with expansion in size and containing many Leydig cells usually surrounded by extensive lymphatic spaces. Blood vessels were especially numerous (Fig. 9).

\section{Morphometric analysis}

The percentage of testis volume (volumetric density) occupied by Leydig cells, the interstitial space, other interstitial cells and the total interstitial compartment was significantly increased 

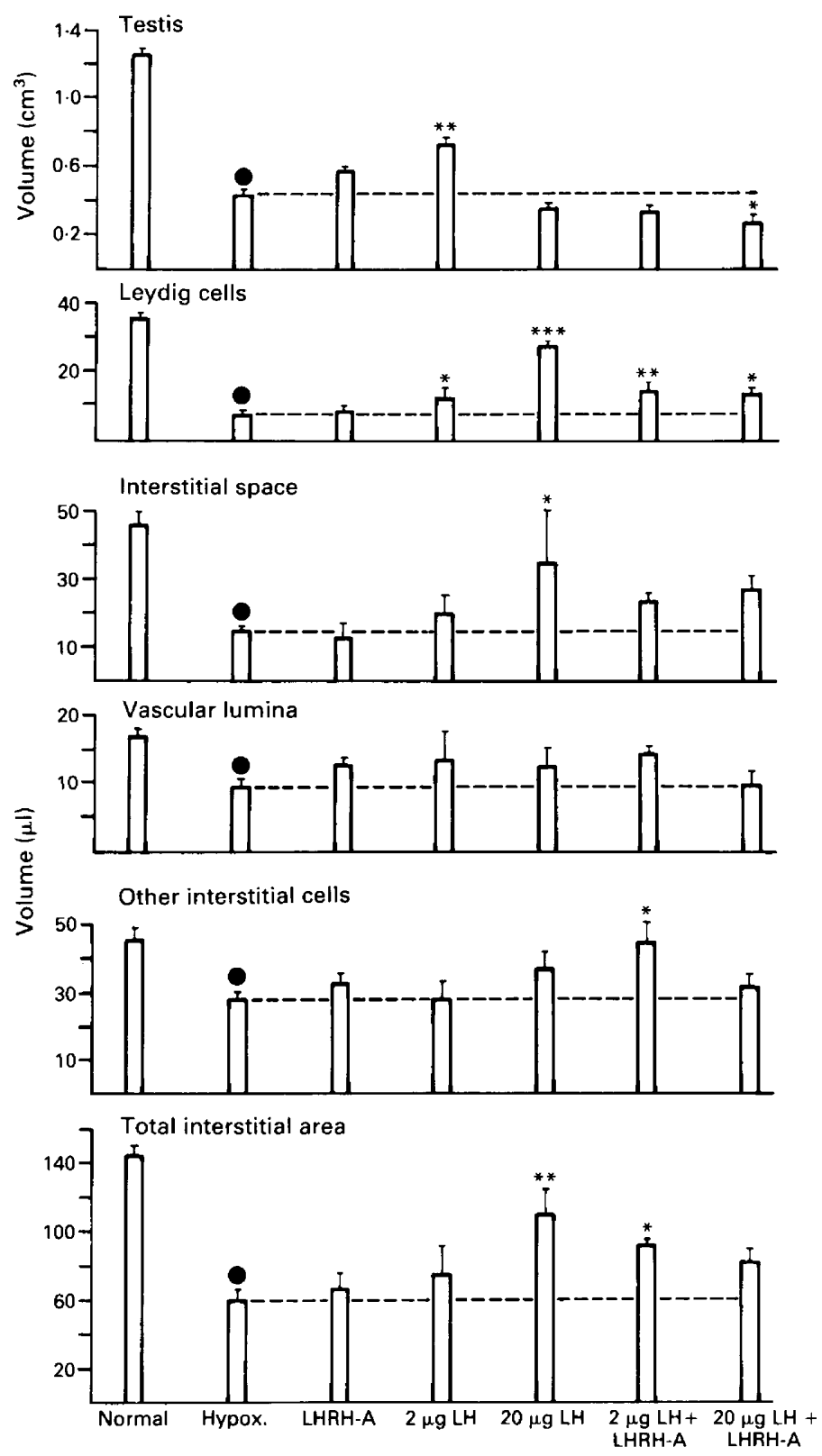

Fig. 11. Absolute volumes of testes, the interstitial compartment and its components in the normal intact adult rat and in saline- or hormone-treated adult hypophysectomized rats. Values expressed as means \pm s.d., $n=3$ in each group. $\boldsymbol{P}, P<0.05$ compared with value for normal testis; ${ }^{*} P<0.05,{ }^{* *} P<0.01,{ }^{* * *} P<0.001$ compared with value for saline-treated hypophysectomized rats.

$(P<0.05-0.001)$ when the effects of $20 \mu \mathrm{g} \mathrm{LH}$ and 2 or $20 \mu \mathrm{g} \mathrm{LH}+$ LHRH agonist treatment were compared to those in saline-treated hypophysectomized rats (Fig. 10). No significant differences were noted for the volumetric density of vascular lumina for any hormone treatment. Treatment with LHRH agonist or $2 \mu \mathrm{g} \mathrm{LH}$ did not significantly change the above parameters compared to 
saline treatment, except for the volumetric density of other interstitial cells which was significantly less $(P<0.01)$ after $2 \mu \mathrm{g}$ treatment. When volumetric density data were converted to absolute volumes per whole testis, total Leydig cell volume was significantly increased $(P<0.05-0.001)$ when treatment with 2 or $20 \mu \mathrm{g} \mathrm{LH}$ and 2 or $20 \mu \mathrm{g} \mathrm{LH}+$ LHRH agonist was compared to salinetreated rats (Fig. 11). Compared to saline treatment, the total interstitial tissue volume was significantly increased $(P<0.05)$ by $20 \mu \mathrm{g} \mathrm{LH}$ treatment. Total volume of other interstitial cells was significantly increased $(P<0.05)$ with $2 \mu \mathrm{g} \mathrm{LH}+\mathrm{LHRH}$ agonist treatment, and the total volume of the interstitial compartment was significantly increased $(P<0.05-0.01)$ after $20 \mu \mathrm{g} \mathrm{LH}$ and $2 \mu \mathrm{g} \mathrm{LH}+$ LHRH agonist treatment. The total volume of blood vessel lumina was not significantly changed when hormone-treated groups were compared to saline-treated rats.

\section{Serum concentrations of testosterone}

Vehicle-injected (control) rats had constant low serum values $(0 \cdot 2-0.5 \mathrm{ng} / \mathrm{ml})$ of testosterone at each of the times studied, and these values are within the range for castrated males measured in our

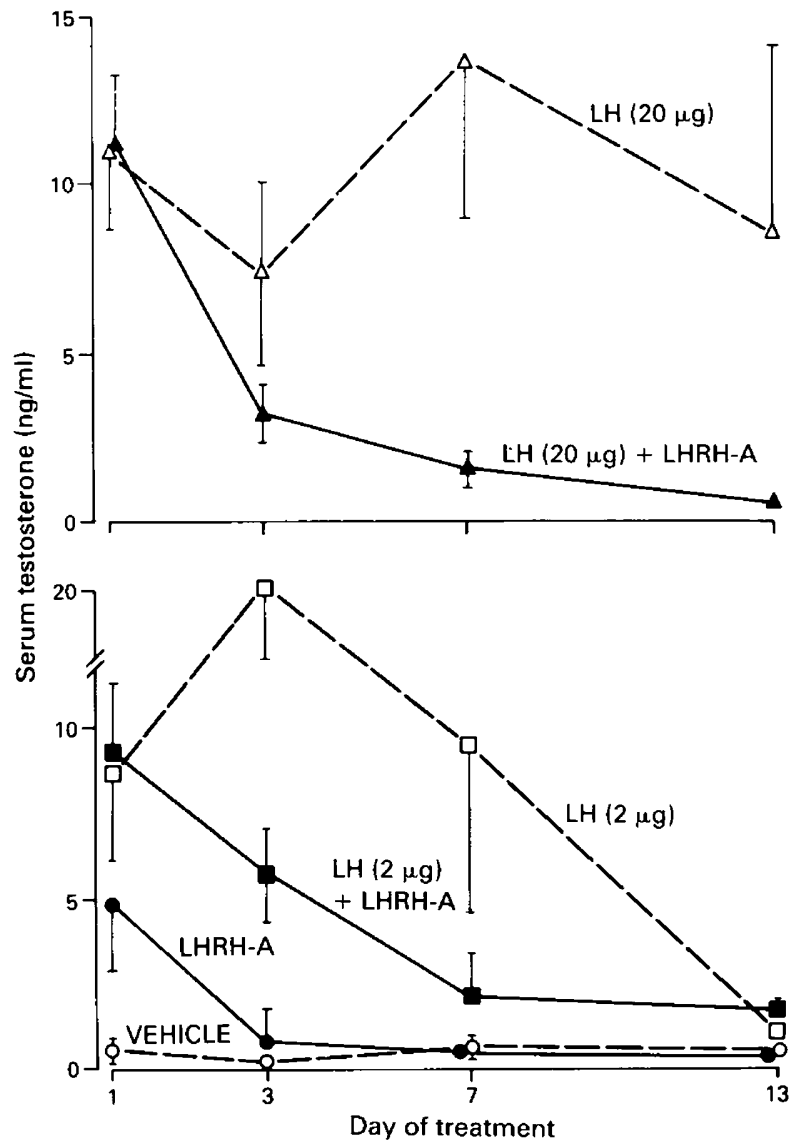

Fig. 12. Serum concentrations of testosterone $2 \mathrm{~h}$ after injection of vehicle, $\mathrm{LH}, \mathrm{LHRH}$ agonist (LHRH-A), or the two hormones in combination, during prolonged daily treatment of hypophysectomized adult rats. Each point is the mean \pm s.d. for 7 (Days 1, 3 and 7) or 4 (Day 13) rats. 


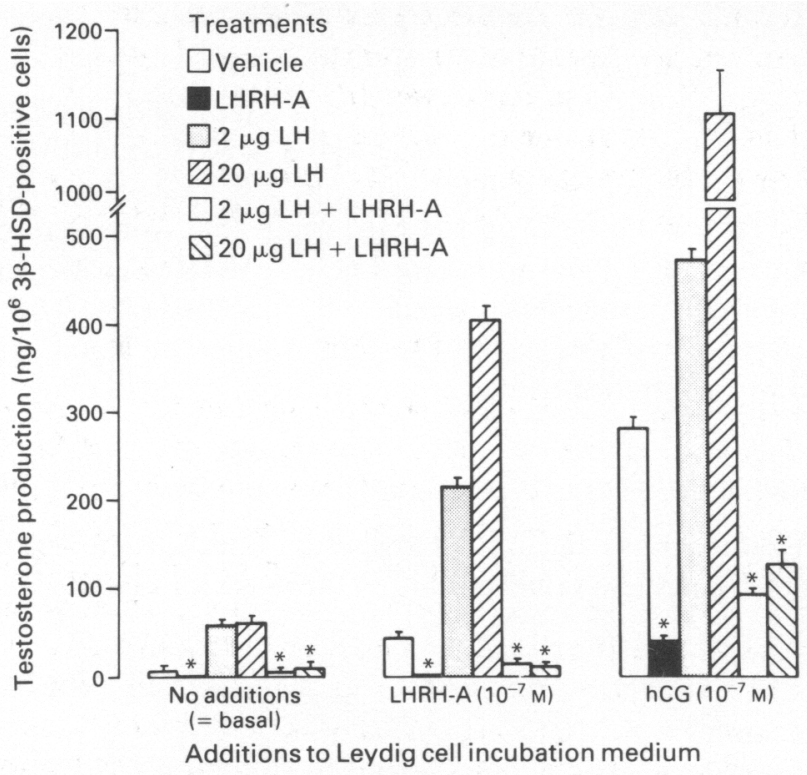

Fig. 13. Testosterone production in vitro by isolated Leydig cells from hypophysectomized adult rats treated for 13 days with vehicle, LH, LHRH agonist (LHRH-A) or the two hormones in combination. Cells were prepared $24 \mathrm{~h}$ after the last injection. Bars are the mean \pm s.d. for triplicate incubations. Asterisks have been used to indicate where in-vivo treatment with LHRH-A, on its own or with LH, has significantly $(P<0.001)$ reduced testosterone production by isolated Leydig cells in vitro, when compared with cells from the corresponding group treated in vivo with vehicle or LH alone.

laboratory (unpublished data). Injection of $100 \mathrm{ng}$ LHRH agonist on Day 1 resulted in an 8-fold increase $(P<0.001)$ in the values of testosterone $2 \mathrm{~h}$ later, compared with controls, but at subsequent sampling times this stimulatory effect was not evident (Fig. 12). At $2 \mathrm{~h}$ after injection of $2 \mu \mathrm{g}$ LH there was a significant $(P<0.001)$ increase in testosterone concentrations on Days 1,3 and 7 of treatment but on Day 13 no significant increase occurred. In contrast, injection of $20 \mu \mathrm{g} \mathrm{LH}$ resulted in a significant $(P<0.001)$ and relatively constant increase in serum testosterone levels at all of the sampling times (Fig. 12).

Injection of $100 \mathrm{ng}$ LHRH agonist together with either of the doses of LH, had no significant effect on testosterone values on Day 1, but thereafter grossly attenuated the LH-stimulated increase in testosterone concentrations $(P<0.05$ to $P<0.001)$, an effect that became progressively more marked with time (Fig. 12).

\section{Testosterone production by isolated Leydig cells}

Leydig cells isolated from the testes of vehicle-injected rats produced low amounts of testosterone basally, but responded to addition of LHRH agonist or hCG by increasing testosterone production 7- and 47-fold, respectively (Fig. 13). Leydig cells isolated from the testes of rats treated with LHRH agonist alone showed an $85 \%$ reduction in basal testosterone production, when compared with cells from control rats, and whereas there was still a significant $(P<0.001)$ response to LHRH agonist (3-fold) or hCG (43-fold), the levels of testosterone achieved were only $6 \%$ and $14 \%$, respectively, of the comparable control values. Compared with controls, treatment of rats with 2 or $20 \mu \mathrm{g}$ LH caused major $(P<0.001)$ increases in basal testosterone production and in responsiveness of the Leydig cells to LHRH agonist or hCG; the last two values were also significantly higher $(P<0.001)$ for rats treated with 20 as opposed to $2 \mu \mathrm{g} \mathrm{LH}$ (Fig. 13). 
Treatment of rats with $\mathrm{LH}+\mathrm{LHRH}$ agonist completely blocked $(P<0.001)$ the stimulatory effects of the LH treatment and lowered the responsiveness of Leydig cells to LHRH agonist or hCG, to levels below that of cells from control rats $(P<0.001$; Fig. 13). Compared with cells from rats treated with $\mathrm{LH}$ alone, testosterone production by cells from rats treated with $\mathrm{LH}+\mathrm{LHRH}$ agonist was reduced by the following amounts: basal values: $92 \%(2 \mu \mathrm{g} \mathrm{LH})$ and $82 \%(20 \mu \mathrm{g} \mathrm{LH})$ reduction; LHRH agonist-stimulated values: $94 \%$ and $96 \%$ reduction; hCG-stimulated values: $80 \%$ and $88 \%$ reduction.

\section{Discussion}

Administration of LHRH and its agonists to immature or adult rats is known to reduce $\mathrm{LH}$ (hCG) receptors in the testis and to impair the steroidogenic capacity of the Leydig cells and this has been proposed to explain the resulting disruption of the seminiferous epithelium which is normally dependent upon stimulation by testosterone. Three possible mechanisms have been suggested to explain these antigonadal actions of LHRH and its agonists (Hsueh \& Jones, 1981): (i) chronic stimulation by LHRH agonists may desensitize the anterior pituitary, resulting in diminished circulating gonadotrophins and atrophy of testicular functions; (ii) high doses of LHRH agonists may cause hypersecretion of LH from the pituitary, causing desensitization of Leydig cells and subsequent spermatogenic impairment; and (iii) LHRH agonists may exert direct inhibitory actions on the testis. To test the involvement of pituitary factors in bringing about the anti-testicular effects of LHRH agonists, previous studies have shown that LHRH agonist treatment of immature or adult hypophysectomized rats does not result in any histological changes in the testis compared to saline-treated hypophysectomized rats (Rivier et al., 1979; Labrie et al., 1980b; Pelletier et al., 1980), suggesting the importance of the pituitary in mediating the anti-spermatogenic actions of LHRH agonists. The present quantitative analysis supports these qualitative findings since treatment of hypophysectomized rats with LHRH agonist alone did not significantly alter testis weight or the morphology of the seminiferous epithelium and interstitial tissue, compared to saline-treated control rats. Despite the lack of morphological changes in the testis of hypophysectomized rats after LHRH agonist treatment, direct inhibitory effects of LHRH agonist upon Leydig cell function were indicated by significant impairment of the ability of isolated Leydig cells to secrete testosterone in vitro when stimulated with LHRH agonist or hCG, in agreement with other studies (Hsueh \& Erickson, 1979; Bambino et al., 1980; Wang et al., 1983). Since LHRH agonists act directly upon Leydig cells (Sharpe et al., 1983b) but are unable to disrupt the spermatogenic process in hypophysectomized animals, then the moderate to severe spermatogenic damage caused by treatment of intact animals with LHRH agonists may be related to additional effects of agonists upon the pituitary resulting in disturbances of gonadotrophin secretion and subsequent major impairment of Leydig cell function. However, concomitant administration of testosterone or dihydrotestosterone to LHRH agonist treated intact rats is unable to prevent seminiferous tubular disruption (Rivier et al., 1979; Pelletier et al., 1980) whereas in the absence of the pituitary, androgens plus LHRH agonists support qualitatively normal spermatogenesis (Rivier et al., 1979). These findings exclude the possibility that the anti-spermatogenic effects of LHRH agonists given to intact rats are due to a decrease in androgen concentrations within the testis, and again point to pituitary factors in mediating the actions of LHRH agonists on the testis. Alternatively, the antigonadal effects of LHRH agonists in intact rats suggest that pituitary factors may themselves exert deleterious effects upon the testis, particularly in combination with LHRH agonist treatment. Our results suggest that $\mathrm{LH}$, either alone or in combination with LHRH agonist, brings about marked disruption of spermatogenesis and alteration of Leydig cell function in hypophysectomized rats. Treatment of hypophysectomized rats with $20 \mu \mathrm{g} \mathrm{LH}$ or 2 or $20 \mu \mathrm{g} \mathrm{LH}+$ LHRH agonist resulted in a decline in testis weight, focal disruption of the seminiferous epithelium and a significant increase in the total volume of Leydig cells within the testis, However, administration of a lower dose of $2 \mu \mathrm{g} \mathrm{LH}$ to hypophysectomized rats stimulated spermatogenesis, significantly increased the 
total Leydig cell volume and increased testis volume compared to saline-treated control rats. The accompanying morphometric results allow two conclusions: (1) the anti-spermatogenic effects of LHRH agonist were expressed in the presence of low or high concentrations of LH and (2) LH alone may exert deleterious effects upon spermatogenesis but this action is dependent upon high concentrations of the hormone. The response of the testis of hypophysectomized rats treated with $20 \mu \mathrm{g} \mathrm{LH}$ and 2 or $20 \mu \mathrm{g} \mathrm{LH}+\mathrm{LHRH}$ agonist ranged from moderate to severe disruption of spermatogenesis and in the latter two treatment groups, tubules devoid of nuclei (and therefore of cells) were commonly observed. Remarkably, tubules often devoid of epithelial cells were commonly observed adjacent to those showing only moderate cellular disruption, normally lacking elongating and mature spermatids. A similar patchy but less severe disruption of spermatogenesis has been observed after chronic LHRH agonist treatment of intact rats (Rivier et al., 1979; Labrie et al., 1980a, b; Pelletier et al., 1980; Vickery et al., 1983; Lefebvre et al., 1984). The central role played by $\mathrm{LH}$ in initiating and sustaining variable spermatogenic disruption is supported by other studies in which hCG + PMSG given to intact adult rats for 1-2 weeks caused degeneration of the seminiferous epithelium (Rivier et al., 1979). These findings and those reported here for $20 \mu \mathrm{g} \mathrm{LH}$ treatment suggest that a simple deficiency in testosterone concentration within the testis cannot explain the inhibition of spermatogenesis. Comparable degenerative changes in spermatogenesis occurred when serum testosterone and in-vitro Leydig cell testosterone production was high (with the $20 \mu \mathrm{g} \mathrm{LH}$ treatment) or lowered (as seen with the 2 or $20 \mu \mathrm{g} \mathrm{LH}+$ LHRH agonist treatments). In our studies using $20 \mu \mathrm{g} \mathrm{LH}$ for treatment, although spermatogenesis was impaired, Leydig cells were abundant, their in-vitro steroidogenic responses to hCG or LHRH agonist stimulation were markedly enhanced compared with those of saline-treated controls (1100 and $300 \mathrm{ng}$ testosterone $/ 10^{6}$ Leydig cells respectively) and serum testosterone values were always within or above the normal range for intact rats. In contrast, similar disruptive effects of 2 or $20 \mu \mathrm{g}$ LH + LHRH agonist treatment upon spermatogenesis occurred when the capacity of the increased total volume of Leydig cells to secrete testosterone was always impaired compared to corresponding treatment with 2 or $20 \mu \mathrm{g} \mathrm{LH}$ alone. It is possible that the variations in secretory function of Leydig cells from groups treated with $\mathrm{LH}$ alone or in combination with LHRH agonist result in abnormal patterns of testosterone production depending on the dose of hormone treatment and whether the treatments exert an overall stimulation or inhibition of Leydig cell function as previously suggested by Sharpe et al. (1983a).

Although the mechanism which brings about significant increases in the total volume of Leydig cells was not studied, it probably occurs via a combination of mitosis of Leydig cells (often seen with $20 \mu \mathrm{g} \mathrm{LH}$ treatment) and differentiation of new Leydig cells from a more primitive interstitial cell type. A similar increase in the Leydig cell population occurs in rats chronically stimulated with daily injections of hCG (Christensen \& Peacock, 1980).

While the present data do not provide a full explanation for the anti-spermatogenic effects of the treatment regimens, the results suggest that $\mathrm{LH}$ alone or in combination with LHRH agonist can focally inhibit spermatogenesis and, in certain seminiferous tubule areas, destroy all the cells of the seminiferous epithelium whereas the nearby Leydig cells undergo striking hyperplasia. The deleterious effects upon the seminiferous epithelium cannot be attributed solely to a lack of testosterone, and as they only occur in the presence of $\mathrm{LH}$ it is possible that some other $\mathrm{LH}$ regulated Leydig cell factor(s) is involved but their identity and mode of action remain unknown. The histological data suggest that the patchy disruption of the seminiferous tubules represents some stage-dependent sensitivity of the spermatogenic cycle to the factors which mediate these changes. Disappearance of Sertoli cells and germ cells and their replacement with dense aggregations of extracellular material has also been reported in LHRH agonist treated intact rats (Vickery et al., 1983) but tubules with normal seminiferous epithelia were also seen in the same testis. It is therefore likely that the focal degeneration of seminiferous tubules represents a very localized toxicological effect from which a proportion of seminiferous tubules fail to recover their spermatogenic function (Labrie et al., 1980b; Pelletier et al., 1980; Lefebvre et al., 1984). 
The observations presented in this study further emphasize that agents that disrupt the spermatogenic process also interfere with the Sertoli cells and Leydig cells and provide evidence for the concept that communication between these cell types is involved in the regulation of spermatogenesis.

We thank Jurgen Sandow and Hoechst A.G. for the gift of LHRH agonist; the NIAMDD for ovine LH; Irene Cooper, Ken Donachie and Denis Doogan for technical assistance; and Professor Sir Alistair Currie, Department of Pathology, University of Edinburgh, for access to ultramicrotome equipment. This study was performed while J.B.K. was supported by a C. J. Martin Fellowship from the National Health and Medical Research Council of Australia.

\section{References}

Akhtar, F.B., Marshall, G.R., Wickings, E.J. \& Nieschlag, E. (1983) Reversible induction of azoospermia in rhesus monkeys by constant infusion of a gonadotropin-releasing hormone agonist using osmotic minipumps. J. clin. Endocr. Metab. 56, 534-540.

Akhtar, F.B., Wickings, E.J. \& Nieschlag, E. (1984) Male fertility control with an LHRH agonist: primate studies. In $L H R H$ and its Analogs. Contraceptive and Therapeutic Applications, pp. 77-90. Eds B. H. Vickery, J. J. Nestor and E. S. E. Hafez. MTP Press, Lancaster.

Bambino, T.H., Schreiber, J.R. \& Hsueh, A.J.W. (1980) Gonadotropin-releasing hormone and its agonist inhibit testicular luteinizing hormone receptor and steroidogenesis in immature and adult hypophysectomized rats. Endocrinology 107, 908-917.

Christensen, A.K. \& Peacock, K.C. (1980) Increase in Leydig cell number in testes of adult rats treated chronically with an excess of human chorionic gonadotropin. Biol. Reprod. 22, 383-391.

Corker, C.S. \& Davidson, D.W. (1978) Radioimmunoassay of testosterone in various biological fluids without chromatography. J. Steroid Biochem. 9, 373-374.

Elias, H. \& Hyde, D.M. (1980) An elementary introduction to stereology (quantitative microscopy). $\mathrm{Am}$. J. Anat. 159, 412446.

Heber, D. \& Swerdloff, R.S. (1981) Gonadotropinreleasing hormone analog and testosterone synergistically inhibit spermatogenesis. Endocrinology 108, 2019-2021.

Hsueh, A.J.W. \& Erickson, G.F. (1979) Extra-pituitary inhibition of testicular function by luteinising hormone releasing hormone. Nature, Lond. 281, 66-67.

Hsueh, A.J.W. \& Jones, P.B.C. (1981) Extrapituitary actions of gonadotropin-releasing hormone. Endocrine Rev. 2, 437-461.

Jones, P.B.C. \& Hsueh, A.J.W. (1984) Direct antigonadal actions of LHRH. In $L H R H$ and its Analogs. Contraceptive and Therapeutic Applications, pp. 163-179. Eds B. H. Vickery, J. J. Nestor and E. S. E. Hafez. MTP Press, Lancaster.

Labrie, F., Auclair, C., Cusan, L., Kelly, P.A., Pelletier, G. \& Ferland, L. (1978) Inhibitory effect of LHRH and its agonists on testicular gonadotrophin receptors and spermatogenesis in the rat. Int. J. Androl., Suppl. 2, 303-318.
Labrie, F., Belanger, A., Cusan, L., Sequin, C., Pelletier, G., Kelly, P.A., Reeves, J.J., Lefebvre, F.A., Lemay, A., Gomdeau, Y. \& Raynaud, J.P. (1980a) Antifertility effects of LHRH agonists in the male. $J$. Androl. 1, 209-228.

Labrie, F., Cusan, L., Sequin, C., Belanger, A., Pelletier, G., Reeves, J., Kelly, P.A., Lemay, A. \& Raynaud, J.P. (1980b) Antifertility effects of LHRH agonists in the male rat and inhibition of testicular steroidogenesis in man. Int. J. Fertil. 25, 157-170.

Lefebvre, F.A., Belanger, A., Pelletier, G. \& Labrie, F. (1984) Recovery of gonadal functions in the adult male rat following cessation of five-month daily treatment with an LHRH agonist. J. Androl. 5, 181-192.

Linde, R., Doelle, G.C., Alexander, N., Kirchner, F., Vale, W., Rivier, J. \& Rabin, D. (1981) Reversible inhibition of testicular steroidogenesis and spermatogenesis by a potent gonadotropin-releasing hormone agonist in normal men. $N$. Engl. J. Med. 305, 663-667.

Pelletier, G., Cusan, L., Auclair, C., Kelly, P.A., Desy, L. \& Labrie, F. (1978) Inhibition of spermatogenesis in the rat by treatment with [D-Ala ${ }^{6}$, Des-Gly- $\mathrm{NH}_{2}{ }^{10}$ ] LHRH ethylamide. Endocrinology 103, 641-643.

Pelletier, G., Cusan, G.L., Belanger, A., Sequin, C., Kelly, P.A. \& Labrie, F. (1980) Further studies on the inhibitory effect of $\left[\mathrm{D}-\mathrm{Ala}{ }^{6}\right.$, des-Gly- $\left.\mathrm{NH}_{2}{ }^{10}\right] \mathrm{LHRH}$ ethylamide on spermatogenesis and steroidogenesis in the rat: reversibility and effect of androgen administration. J. Androl. 1, 171-181.

Rabin. D., Linde, R., Doelle, G. \& Alexander, N. (1981) Experience with a potent gonadotropin-releasing hormone agonist in normal men: an approach to the development of a male contraceptive. In $L H R H$ Peptides as Female and Male Contraceptives, pp. 296-306. Eds G. I. Zatuchni, J. D. Shelton and J. J. Sciarra. Harper and Row, Philadelphia.

Rajfer, J., Swerdloff, R.S. \& Heber, D.M. (1984) Testicular histology following chronic gonadotropinreleasing hormonc agonist treatment. Fert. Steril. 42, 765-771.

Rivier, C., Rivier, J. \& Vale, W. (1979) Chronic effects of $\left[\mathrm{D}-\operatorname{Trp}^{6}, \mathrm{Pro}^{9}-\mathrm{NEt}\right]$ luteinizing hormone-releasing factor on reproductive processes in the male rat. Endocrinology 105, 1191-1201.

Sandow, J. (1982) Gonadotropic and antigonadotropic actions of LHRH analogues. In Neuroendocrine 
Perspectives, pp. 339-395. Eds E. E. Muller \& R. M. MacLeod. Elsevier, Amsterdam.

Sharpe, R.M. (1984) Intratesticular factors controlling testicular function. Biol. Reprod. 30, 29-49.

Sharpe, R.M. \& Fraser, H.M. (1983) The role of LH in regulation of Leydig cell responsiveness to an $\mathrm{LHRH}$ agonist. Molec. cell. Endocr. 33, 131-146.

Sharpe, R.M., Doogan, D.G. \& Cooper, I. (1983a) Factors determining whether the direct effects of an LHRH agonist on Leydig cell function in vivo are stimulatory or inhibitory. Molec. cell. Endocr. 32, $57-71$.

Sharpe, R.M., Doogan, D.G. \& Cooper, I. (1983b) Direct effects of a luteinizing hormone-releasing hormone agonist on intratesticular levels of testosterone and interstitial fluid formation in intact male rats. Endocrinology 113, 1306-1313.

Tremblay, Y. \& Belanger, A. (1984) Reversible inhibition of gonadal functions by a potent gonadotropinreleasing hormone agonist in adult dogs. Contraception 30, 483-497.
Vickery, B., McRae, G.I., Bergstrom, K., Briones, W., Worden, A. \& Seidenberg, R. (1983) Inability of longterm administration of D-Nal(2) ${ }^{6}-\mathrm{LHRH}$ to abolish fertility in male rats. J. Androl. 4, 283-291.

Vickery, B.H., McRae, G.I., Briones, W., Worden, A., Seidenberg, R., Schanbacher, B.D. \& Falvo, R. (1984) Effects of an LHRH analog upon sexual function in male dogs. Suppression, reversibility, and effect of testosterone replacement. J. Androl. 5, 28-42.

Wang, N.G., Sundaram, K., Pavlou, S., Rivier, J., Vale, W. \& Bardin, C.W. (1983) Mice are insensitive to the antitesticular effects of luteinizing hormone-releasing hormone agonists. Endocrinology 112, 331-335.

Weibel, E.R. (1979) Stereological Methods. Vol. 1, Practical Methods for Biological Morphometry. Academic Press, London.

Received 4 April 1985 